\title{
Photoluminescence Study of Tin Oxide-Zinc Oxide Nanocomposites
}

\author{
K.J. Abhirama ${ }^{*}$, K.U. Madhu² \\ ${ }^{1,2}$ Physics Research Centre, S.T.Hindu College, Nagercoil, India \\ (Affiliated to Manonmaniam Sundaranar University,Abishekapatti, Tirunelveli, India \\ *Corresponding Author: abhiramathampi87@gmail.com, Tel.:04651-278910
}

Available online at: www.isroset.org

Received: 02/Jun/2018, Revised: 11/Jun/2018, Accepted: 23/Jun/2018, Online: 30/Jun/2018

\begin{abstract}
Undoped and $\mathrm{Cu}^{2+}$ doped $\left(\mathrm{SnO}_{2}\right)_{1-\mathrm{x}}(\mathrm{ZnO})_{\mathrm{x}}$ nanocomposites were synthesized using a simple microwave assisted solvothermal method with ethylene glycol as solvent. The as-prepared samples were calcinated at $500{ }^{\circ} \mathrm{C}$ for $1 \mathrm{hr}$. The optical studies were carried out using Photoluminescence measurements. A small shift in the peak position was observed for doped samples when compared to undoped samples. The shifting was due to the incorporation of dopant into the host matrix and also coupled with the variation of band gap energies of the nanocomposites. The results obtained were reported and discussed herewith.
\end{abstract}

Key words: Nanocomposite, Photoluminescence, Solvothermal, Tin oxide, Zinc oxide.

\section{INTRODUCTION}

In the past three decades, nanostructured materials are considered as an exciting research area. Nanotechnology is an interdisciplinary area where the theories in Physics, Chemistry, Biology and Engineering are used to manipulate and design new devices. Nanomaterials are used as safer and efficient product in agriculture, industry, medicine, transport and communication [1]. $\mathrm{SnO}_{2}$ and $\mathrm{ZnO}$ nanoparticles are used as sensors $[2,3,4]$, solar cells [5, 6], catalyst [7, 8], antibacterial agent [9], in lithium ion batteries [10,11] and so on. Luminescence is a phenomenon in which a material when excited with an external source like electrons, photons, etc will emit light in the visible range, UV or IR. The process in which a substance absorbs photons and get excited to a higher energy state and then return to lower energy state with the emission of another photon is termed as photoluminescence. $\mathrm{SnO}_{2}-\mathrm{ZnO}$ nanocomposites can be synthesized via sol-gel method [12-14], hydrothermal [15], co-precipitation method [16, 17], atomic layer deposition technique [18] and spray pyrolysis $[19,20]$. The properties of the nanoparticles can be modified by the inclusion of suitable dopants into the parent matrix.

In the present work the phototoluminescence studies were carried out for $\left(\mathrm{SnO}_{2}\right)_{1-\mathrm{x}}(\mathrm{ZnO})_{\mathrm{x}}$ nanocomposites (with $\mathrm{x}$ values $0.0,0.2,0.4,0.5,0.6,0.8$ and 1.0). Different excitation wavelengths ranging from $272 \mathrm{~nm}$ to $335 \mathrm{~nm}$ were used to record the emission spectra. The results obtained were reported and discussed. This article is organized as follows: Section I gives the introduction about photoluminescence studies. Section II explains the experimentation and characterization of tin oxide- zinc oxide nanocomposites. The results and discussions of the related work are discussed in section III and in the last section IV the conclusions of the research work are given.

\section{EXPERIMENTATION AND CHARACTERIZATION}

Undoped and $\mathrm{Cu}^{2+}$ doped $\left(\mathrm{SnO}_{2}\right)_{1-\mathrm{x}}(\mathrm{ZnO})_{\mathrm{x}}$ nanocomposites ( with $\mathrm{x}$ values 0.0, 0.2, 0.4, 0.5, 0.6, 0.8 and 1.0) were synthesized using a simple microwave assisted solvothermal method. The experimental procedure for the synthesis of undoped and $\mathrm{Cu}^{2+}$ doped $\left(\mathrm{SnO}_{2}\right)_{1-}$ ${ }_{\mathrm{x}}(\mathrm{ZnO})_{\mathrm{x}}$ nanocomposites (with $\mathrm{x}$ values $0.0,0.2,0.4,0.5$, $0.6,0.8$ and 1.0) was explained in detail in our earlier work $[21,22]$. The as prepared samples were calcinated at $500{ }^{\circ} \mathrm{C}$ for $1 \mathrm{hr}$. The photoluminescence measurements of calcinated samples were carried out at room temperature.

\section{RESULTS AND DISCUSSION}

The photoluminescence spectra of undoped and $\mathrm{Cu}^{2+}$ doped $\left(\mathrm{SnO}_{2}\right)_{1-\mathrm{x}}(\mathrm{ZnO})_{\mathrm{x}}$ nanocomposites are shown in Figures 1- 14. Undoped $\mathrm{SnO}_{2}$ nanoparticles show two prominent peaks at 421 and $462 \mathrm{~nm}$. The strong indigo peak at $421 \mathrm{~nm}$ was attributed to electron transition due to oxygen vacancies and defects in $\mathrm{SnO}_{2}$ nanoparticles [23,24]. The strong blue emission peak at $462 \mathrm{~nm}$ was due to electron transition arbitrated by defect levels such as oxygen vacancies in the energy gap [25]. $\left(\mathrm{SnO}_{2}\right)_{1-\mathrm{x}}(\mathrm{ZnO})_{\mathrm{x}}$ nanocomposites with $\mathrm{x}$ values $(0.2,0.4,0.5,0.6$ and 0.8$)$ show prominent peaks at 
415 and $453 \mathrm{~nm} ; 418$ and $460 \mathrm{~nm} ; 419$ and $461 \mathrm{~nm} ; 421$ and $462 \mathrm{~nm} ; 430$ and $465 \mathrm{~nm}$ respectively. The strong violet peaks at 415,418 and $419 \mathrm{~nm}$ and the strong indigo peaks at 421 and $430 \mathrm{~nm}$ are due to electron transitions arbitrated by defects levels in the band gap such as oxygen vacancies or tin interstitials [23, 24]. The strong blue emissions at 453, $460,461,462$ and $465 \mathrm{~nm}$ are due to electron transitions arbitrated by defect levels such as oxygen vacancies in the energy gap [25].

$\mathrm{ZnO}$ nanoparticles show four prominent peaks at 464, 502, 660 and $684 \mathrm{~nm}$. The weak blue emission peak at $464 \mathrm{~nm}$ was ascribed to the transition between the shallow donor levels of zinc vacancies and the shallow acceptor levels of oxygen vacancies [26]. Also the excitons on the surface of $\mathrm{ZnO}$ nanoparticles give rise to emission peak around $465 \mathrm{~nm}$ [27]. The weak green emission peak at 502 $\mathrm{nm}$ was due to the presence of singly ionized oxygen

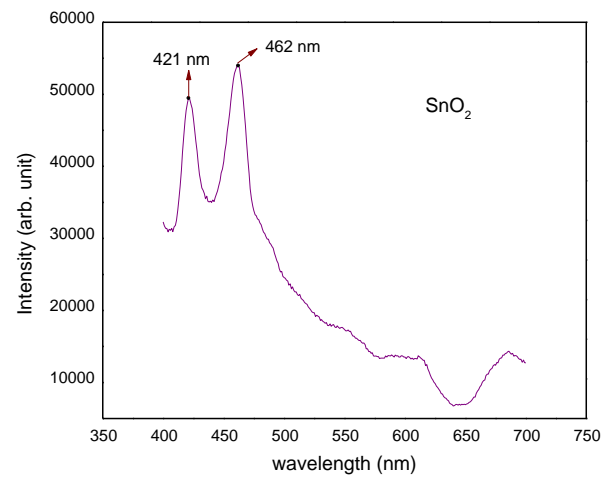

Figure 1: PL spectrum of $\mathrm{SnO}_{2}$ nanoparticles

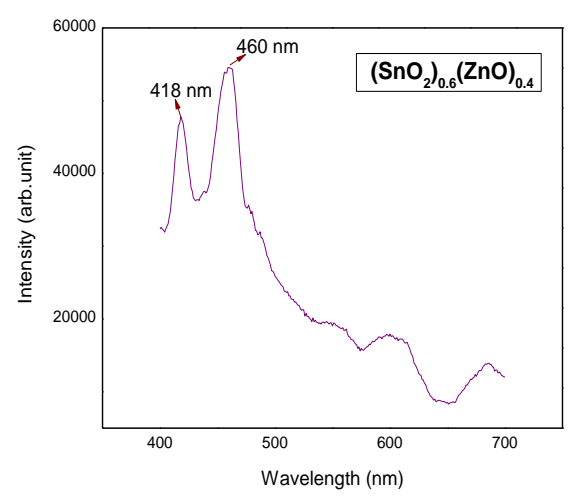

Figure 3: PL spectrum of $\left(\mathrm{SnO}_{2}\right)_{0.6}(\mathrm{ZnO})_{0.4}$ nanocomposite vacancies and the recombination of photogenerated hole with the singly-ionized charge state results in green emission $[28,29]$. The radioactive recombination of a photogenerated hole with an electron occupying the oxygen vacancy causes luminescence emission peak [30]. The occurrence of red emission peaks around 660 and $684 \mathrm{~nm}$ are attributed to deep level emission. Oxygen interstitial defects in $\mathrm{ZnO}$ nanoparticles paved way for deep level emission [31]. The peaks at 660 and $684 \mathrm{~nm}$ are highly intense and the reason for high peak intensity at this region is mainly due to the increase in the number of oxygen vacancies [32]. $\mathrm{Cu}^{2+}$ doped $\left(\mathrm{SnO}_{2}\right)_{1-\mathrm{x}}(\mathrm{ZnO})_{\mathrm{x}}$ nanocomposites show shift in the peak position when compared to undoped $\left(\mathrm{SnO}_{2}\right)_{1-\mathrm{x}}(\mathrm{ZnO})_{\mathrm{x}}$ nanocomposites. The shifting was due to the incorporation of dopant into the host matrix and also coupled with the variation of band gap energies of the nanocomposites [33].

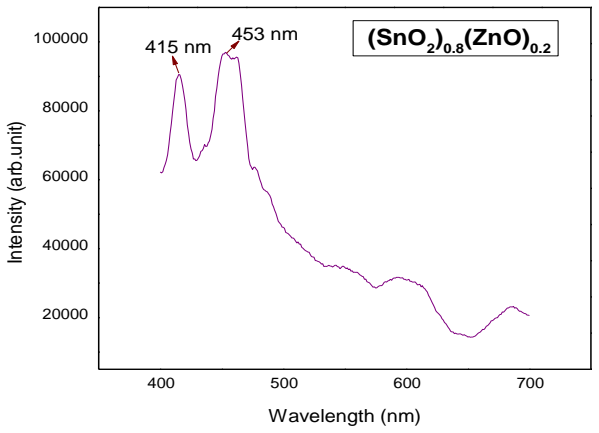

Figure 2: PL spectrum of $\left(\mathrm{SnO}_{2}\right)_{0.8}(\mathrm{ZnO})_{0.2}$ nanocomposite

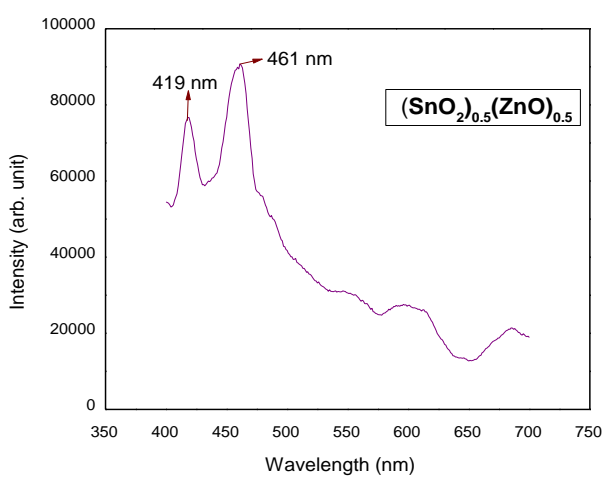

Figure 4: PL spectrum of $\left(\mathrm{SnO}_{2}\right)_{0.5}(\mathrm{ZnO})_{0.5}$ nanocomposite 


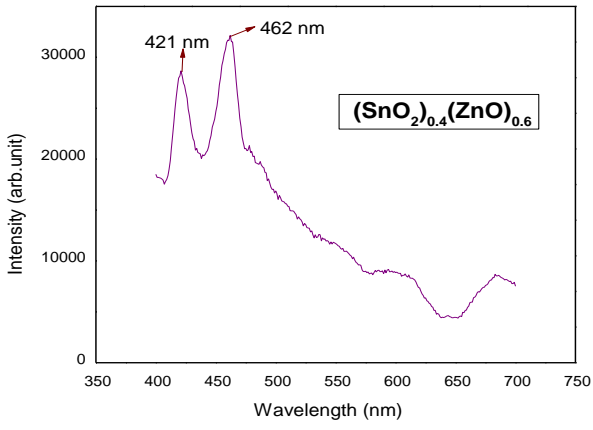

Figure 5: PL spectrum of $\left(\mathrm{SnO}_{2}\right)_{0.4}(\mathrm{ZnO})_{0.6}$ nanocomposite

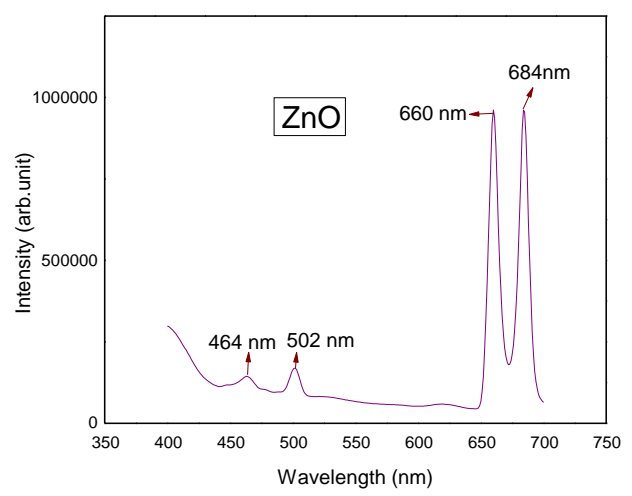

Figure 7: PL spectrum of $\mathrm{ZnO}$ nanoparticles

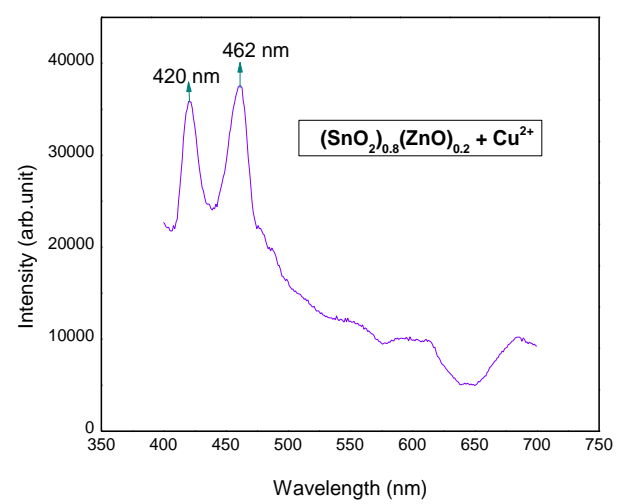

Figure 9: PL spectrum of $\left(\mathrm{SnO}_{2}\right)_{0.8}(\mathrm{ZnO})_{0.2}+$ $\mathrm{Cu}^{2+}$ nanocomposite

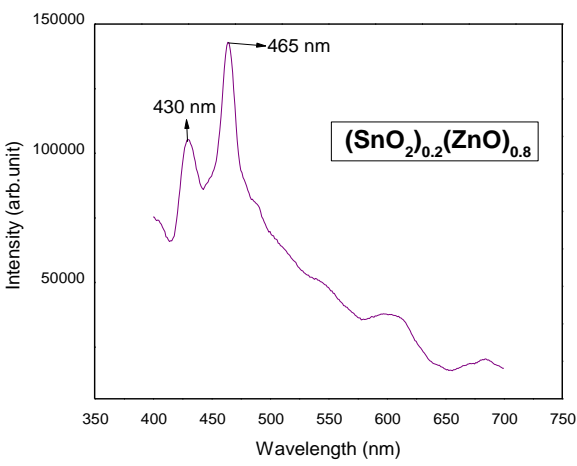

Figure 5: PL spectrum of $\left(\mathrm{SnO}_{2}\right)_{0.2}(\mathrm{ZnO})_{0.8}$ nanocomposite

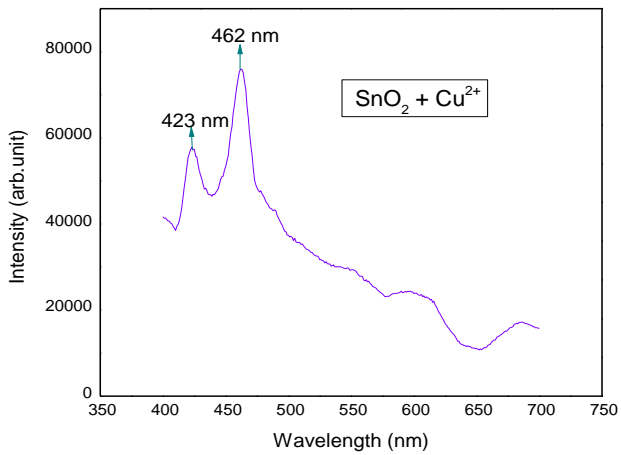

Figure 8: PL spectrum of $\mathrm{SnO}_{2}+\mathrm{Cu}^{2+}$ nanoparticles

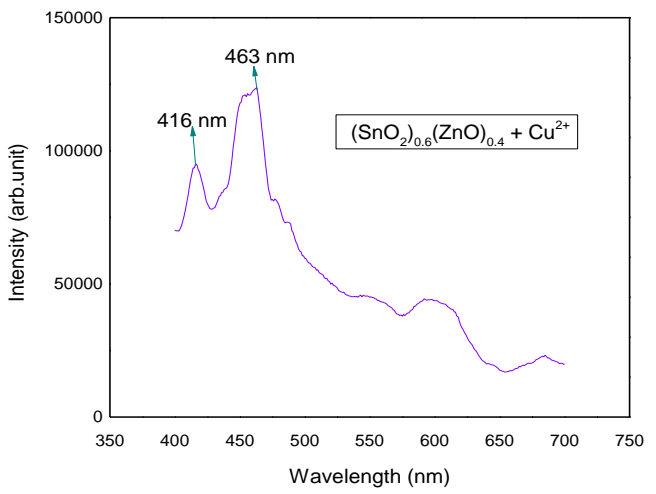

Figure 10: PL spectrum of $\left(\mathrm{SnO}_{2}\right)_{0.6}(\mathrm{ZnO})_{0.4}+$ $\mathrm{Cu}^{2+}$ nanocomposite 


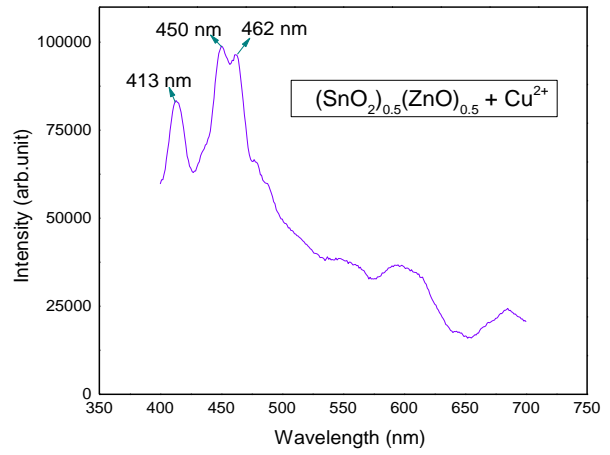

Figure 11: PL spectrum of $\left(\mathrm{SnO}_{2}\right)_{0.5}(\mathrm{ZnO})_{0.5}+$ $\mathrm{Cu}^{2+}$ nanocomposite

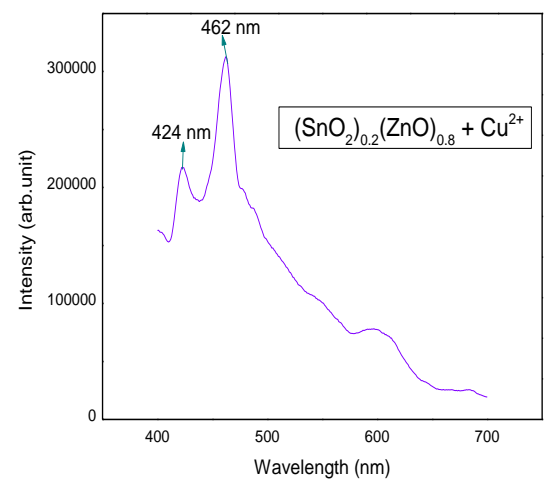

Figure 13: PL spectrum of $\left(\mathrm{SnO}_{2}\right)_{0.2}(\mathrm{ZnO})_{0.8}+$ $\mathrm{Cu}^{2+}$ nanocomposite

\section{CONCLUSION}

The PL spectra of $\mathrm{SnO}_{2}$ nanoparticles show two prominent peaks at 421 and $462 \mathrm{~nm}$. $\left(\mathrm{SnO}_{2}\right)_{1-\mathrm{x}}(\mathrm{ZnO})_{\mathrm{x}}$ nanocomposites with $\mathrm{x}$ values $(0.2,0.4,0.5,0.6$ and 0.8$)$ show prominent peaks at 415 and $453 \mathrm{~nm} ; 418$ and $460 \mathrm{~nm} ; 419$ and $461 \mathrm{~nm} ; 421$ and $462 \mathrm{~nm} ; 430$ and $465 \mathrm{~nm}$ respectively. While $\mathrm{ZnO}$ nanoparticles show four prominent peaks at 464, 502, 660 and $684 \mathrm{~nm}$ respectively. Shifting in the peak position of $\mathrm{Cu}^{2+}$ doped $\left(\mathrm{SnO}_{2}\right)_{1-\mathrm{x}}(\mathrm{ZnO})_{\mathrm{x}}$ nanocomposites when compared to undoped $\left(\mathrm{SnO}_{2}\right)_{1}$. ${ }_{x}(\mathrm{ZnO})_{\mathrm{x}}$ nanocomposites was observed. The shifting was mainly due to the incorporation of dopant into the host matrix and also it was coupled with the variation of band gap energies.

\section{REFERENCES}

[1]. M. A. Shah, Tokeer Ahmad, "Principles of Nanoscience and Nanotechnology", Narosa Publishing Houses Pvt, Ltd, New Delhi, 2010.

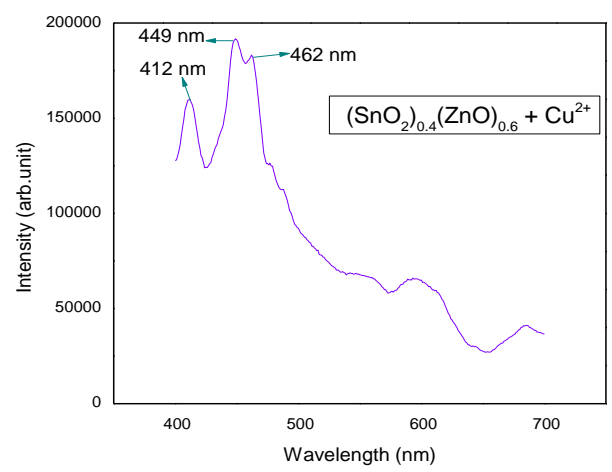

Figure 12: PL spectrum of $\left(\mathrm{SnO}_{2}\right)_{0.4}(\mathrm{ZnO})_{0.6}+$ $\mathrm{Cu}^{2+}$ nanocomposite

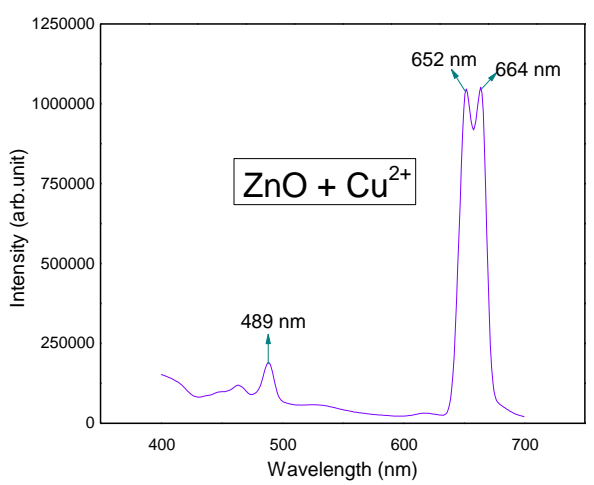

Figure 14: $\mathrm{PL}$ spectrum of $\mathrm{ZnO}+\mathrm{Cu}^{2+}$ nanoparticles

[2]. R. Leghrib, E. Llobet, R. Pavelko, A. A. Vasiliev, A. Felten, J. J. Pireaux, "Gas sensing properties of MWCNTs decorated with gold or tin oxide nanoparticles", Procedia Chemistry, vol. 1, pp. 168-171, 2009.

[3]. Kengo Shimanoe, Aya Nishiyama, Masayoshi Yuasa, Tetsuya Kida, Noboru Yamazoe, "Microstructure control of $\mathrm{WO}_{3}$ film by adding nano-particles of $\mathrm{SnO}_{2}$ for $\mathrm{NO}_{2}$ detection in ppb level", Procedia Chemistry, vol. 1, pp. 212-215, 2009.

[4]. Artem Marikutsa, Valery Krivetskiy, Marina Rumyantseva, Elizaveta Konstantinova, Andrea Ponzoni, Elisabetta Comini, Alexander Gaskov, "Catalytic impact of $\mathrm{RuO}_{\mathrm{x}}$ clusters to high $\mathrm{NH}_{3}$ sensitivity of tin dioxide", Procedia Engineering, vol. 25, pp. $227-230,2011$

[5]. Komol Kanta Sharker, A. Mubarak Khan, M. M. Shauk Khan, Rafiqul Islam, "Preparation and Characterization of Tin Oxide based Transparent Conducting Coating for Solar Cell Application", Int. J. Thin. Fil. Sci. Tec., vol. 4, no. 3, pp. 243 247, 2015.

[6]. Supphadate Sujinnapram, Sasimonton Moungsrijun, "Additive $\mathrm{SnO}_{2}-\mathrm{ZnO}$ composite photoanode for improvement of power conversion efficiency in dye-sensitized solar cell", Procedia Manufacturing, vol. 2, pp. 108 - 112, 2015.

[7]. Nasibeh Shahrivar Fallah, Masoud Mokhtary, "Tin oxide nanoparticles $\left(\mathrm{SnO}_{2}-\mathrm{NPs}\right)$ : An efficient catalyst for the one-pot 
synthesis of highly substituted imidazole derivatives", Journal of Taibah University for Science, vol. 9 , pp. 531-537, 2015.

[8]. Manuela Stan, Adriana Popa, Dana Toloman, Adriana Dehelean, Ildiko Lung, Gabriel Katona, "Enhanced photocatalytic degradation properties of zinc oxide nanoparticles synthesized by using plant extracts", Materials Science in Semiconductor Processing, vol. 39, pp. 23-29, 2015.

[9]. Tamanna Bhuyan, Kavita Mishra, Manika Khanuja, Ram Prasad, Ajit Varma, "Biosynthesis of zinc oxide nanoparticles from Azadirachta indica for antibacterial and photocatalytic applications", Materials Science in Semiconductor Processing, vol. 32, pp. 55-61, 2015.

[10]. Jun Song Chen, Xiong Wen (David) Lou, " $\mathrm{SnO}_{2}$ and $\mathrm{TiO}_{2}$ nanosheets for lithium-ion batteries", Materials Today, vol.15, no.6, pp. 246-254, 2012.

[11]. Franziska Mueller, Dominic Bresser, Venkata Sai Kiran Chakravadhanula, Stefano Passerini, "Fe-doped $\mathrm{SnO}_{2}$ nanoparticles as new high capacity anode material for secondary lithium-ion batteries", Journal of Power Sources, vol. 299, pp. 398-402, 2015.

[12]. Karzan Abdulkareem Omar, Bashdar Ismael Meena, Srwa Ali Muhammed, "Study on the activity of $\mathrm{ZnO}-\mathrm{SnO}_{2}$ nanocomposite against bacteria and fungi", Physicochem. Probl. Miner. Process, vol. 52(2), pp. 754-766, 2016.

[13]. Nasrin Talebian, Mohammad Reza Nilforoushan, Elahe Badri Zargar, "Enhanced antibacterial performance of hybrid semiconductor nanomaterials: $\mathrm{ZnO} / \mathrm{SnO}_{2}$ nanocomposite thin films", Applied Surface Science, vol. 258, pp. 547- 555, 2011.

[14]. Suresh Kumar, Ravi Nigam, Virender Kundu, Neena Jaggi, "Sol-gel synthesis of $\mathrm{ZnO}-\mathrm{SnO}_{2}$ nanocomposites and their morphological, structural and optical properties", J Mater Sci: Mater Electron, 7 pages, 2015.

[15]. Xiaohua Jia, Huiqing Fan, Lei Qin, Chao Yang, "Hierarchically Structure $\mathrm{SnO}_{2} / \mathrm{ZnO}$ Nanocomposites: Preparation, Growth Mechanism and Gas Sensing Property", Journal of Dispersion Science and Technology, vol. 31, pp. 1405-1408, 2010.

[16]. Prasopporn Junlabhut, Wanichaya Mekprasart, Russameeruk Noonuruk, Krisana Chongsri, Wisanu Pecharapa, "Characterization of $\mathrm{ZnO}: \mathrm{Sn}$ nanopowders synthesized by coprecipitation method", Energy Procedia , vol. 56, pp. 560 - 565, 2014.

[17]. C. Kahattha, K. Chongsri, R. Noonuruk, W. Mekprasart, W. Pecharapa, "Effect of tin loading on physical properties and phase transformation of as-synthesized $\mathrm{Zn}-\mathrm{Sn}-\mathrm{O}$ compound powder synthesized by co-precipitation method", Energy Procedia, vol. 56, pp. $673-677,2014$.

[18]. Woon-Seop Choi, "Preparation of Zinc-tin-oxide Thin Film by Using an Atomic Layer Deposition Methodology", Journal of the Korean Physical Society, vol. 57, no. 6, pp. 1472-1476, 2010.

[19]. L. A. Patil, I. G. Pathan, D. N. Suryawanshi, A. R. Bari, D. S. Rane, "Spray pyrolyzed $\mathrm{ZnSnO}_{3}$ nanostructured thin films for hydrogen Sensing", Procedia Materials Science, vol. 6, pp. 1557 $-1565,2014$.

[20]. R. H. Bari, S. B. Patil, A. R. Bari, "Chemically Sprayed Nanocomposite $\mathrm{SnO}_{2}-\mathrm{ZnO}$ Thin Film for Ethanol Gas Sensor", Journal of Nanoengineering and Nanomanufacturing, vol. 3, pp. 1-5, 2013.
[21]. K. J. Abhirama, K. U. Madhu, " Electrical Parameters of $\left(\mathrm{SnO}_{2}\right)_{1-\mathrm{x}}(\mathrm{ZnO})_{\mathrm{x}}$ nanocomposites prepared by solvothermal method ", International Journal of Advance Engineering and Research Development, Volume 4, Issue 09, pp. 511-518, 2017.

[22]. K. J. Abhirama, K. U. Madhu, "Synthesis and Electrical Characterization of $\mathrm{Cu}^{2+}$ doped $\left(\mathrm{SnO}_{2}\right)_{1-\mathrm{x}} \quad(\mathrm{ZnO})_{\mathrm{x}}$ nanocomposites", Int. Journal of Engineering Research and Application, Vol.7,Issue 11, Part -7, pp.64-72, 2017.

[23]. N. Asama Naje, S. Azhar Norry, M. Abdulla Suhail, "Preparation and Characterization of $\mathrm{SnO}_{2}$ Nanoparticles", International Journal of Innovative Research in Science, Engineering and Technology, vol. 2, Issue 12, pp. 7068- 7072, 2013.

[24]. M. Saravanakumar, S. Agila, N. Muthukumarasamy, V. Rukkumani, A. Marusamy, P. Uma mahshwari, A. Ranjitha, "Photoluminescence Studies on Nanocrystalline Pure and $\mathrm{Cr}$ Doped Tin Oxide Powder", Int.J. ChemTech Res, vol. 6, no. 14, pp. 5429-5432, 2014.

[25]. Nurul Syahidah Sabri, Mohd Salleh Mohd Deni, Azlan Zakaria, Mahesh Kumar Talari, "Effect of Mn Doping on Structural and Optical Properties of $\mathrm{SnO}_{2}$ Nanoparticles Prepared by Mechanochemical Processing”, Physics Procedia , vol. 25, pp. $233-239,2012$

[26]. Xiaojuan Wu, Zhiqiang Wei, Lingling Zhang, Xuan Wang, Hua Yang, Jinlong Jiang, "Optical and Magnetic Properties of Fe doped $\mathrm{ZnO}$ Nanoparticles obtained by Hydrothermal Synthesis", Journal of Nanomaterials, vol. 2014, 6 pages, 2014.

[27]. Laishram Robindro Singh, "Photoluminescence Studies of $\mathrm{ZnO}$, $\mathrm{ZnO}: \mathrm{Eu}$ and $\mathrm{ZnO}: \mathrm{Eu}$ Nanoparticles Covered with $\mathrm{Y}_{2} \mathrm{O}_{3}$ Matrix", Materials Sciences and Applications, vol. 6, pp. 269 278, 2015.

[28]. Amita Verma, A. K. Srivastava, "Sol-gel derived nanostructured zinc oxide for bright luminescence in ultraviolet and visible spectral regions", Indian Journal of Chemistry, vol. 50A, pp. 1697-1702, 2011.

[29]. Elaheh Kowsari, Mohammad Reza Ghezelbash, "Ionic liquidassisted, facile synthesis of $\mathrm{ZnO} / \mathrm{SnO}_{2}$ nanocomposites, and investigation of their photocatalytic activity", Materials Letters, vol. 68, pp. 17-20, 2012.

[30]. Satyanarayana Talam, Srinivasa Rao Karumuri, Nagarjuna Gunnam, "Synthesis, Characterization, and Spectroscopic Properties of ZnO Nanoparticles", ISRN Nanotechnology, vol. 2012, 6 pages, 2012.

[31]. K.Jeyasubramaniam, G.S. Hikku, R. Krishna Sharma, "Photocatalytic degradation of methyl violet dye using zinc oxide nano particles prepared by a novel precipitation method and its antibacterial activities", Journal of Water Process Engineering, vol.8, pp. 35-44, 2015.

[32]. Mehar Bhatnagar, Vishakha Kaushik, Akshey Kaushal, Mandeep Singh, Bodh Raj Mehta, "Structural and photoluminescence properties of tin oxide and tin oxide: $\mathrm{C}$ core-shell and alloy nanoparticles synthesised using gas phase technique", AIP Advances, vol. 6, issue. 9, 12 pages, 2016.

[33]. Edgar Mosquera, Carolina Rojas-Michea, Mauricio Morel, Francisco Gracia, Victor Fuenzalida, A.Ramón Zárate, "Zinc oxide nanoparticles with incorporated silver: Structural, morphological, optical and vibrational properties", Applied Surface Science, vol. 347 , pp. 561 